mended this to all practitioners in the field. The commission also made it clear that the responsibility for the safety of this work lies with the principal investigator.

Professor Werner Arber of the Biozentrum at the University of Basle, and one of the 1978 Nobel Laureates in Medicine is a member of the commission. Commenting on the responsibility of the investigator, he told Nature that: "It is perhaps important to say that the Swiss Law of Epidemics foresees that any work with pathogens and their products has to be carried out with the maximum of care, and our commission interprets this formulation in such a way that recombinant DNA [research] done in our country has also to be done with a maximum of care".

The commission compiles an annual register of all work done in genetic engineering. In 1978 there were some 31 projects in the field under 18 principal investigators, eight of whom were based in Basle. The projects are divided into two groups according to their source of DNA for recombination. Category ' $a$ ' experiments are those using cellular DNA and using $E$. coli as host; and category ' $b$ ' includes those using DNA from plasmids, bacteriophage and viruses and again using $E$. coli as the host. Twenty-two of the projects are in category ' $a$ ' and include work with embryological tissue from primates, other mammals, birds and cold blooded vertebrates. Eight of the 'a' category are listed as using 'inferior eukaryotes' as a source of DNA. In category ' $b$ ' the recombination work is listed as involving plant viruses, $99 \%$ pure organelle DNA from eukaryotes (but not primates) and plasmids or phage DNA from hosts, the genes of which are interchangeable with $E$. coli.

Of the 18 principal investigators 15 are based in universities, with the remaining three privately sponsored.

It is the European Science Foundation (ESF) which is trying to harmonise the guidelines and working conditions in recombinant DNA research in Europe. Arber represents the Swiss Commission at the ESF meetings and appreciates the effort the Foundation is making to find the common ground. However, Arber says that the Swiss Commission has still not reached a firm decision on the guidelines it will adopt in the future. In the next few months the commission will meet again to consider the revised NIH guidelines (which lift restrictions on some categories of recombinant DNA research, but which for the first time extend the controls to cover industry), those of the UK Genetic Manipulation Advisory Group, and the guidelines proposed for France and Germany.

Alastair Hay

\title{
Catch a falling Kosmos-and send the bill to Moscow
}

Operation Morninglight-the clean-up of northern Canada, following the "unscheduled re-entry" and crash of the Soviet satellite Kosmos-954 a year ago is now over, at a cost of some $\$ 13$ million. Canada is sending a bill for $\$ 6$ million to the Soviet Union.

Kosmos-954, which carried a powersource fuelled with some $50 \mathrm{~kg}$ of enriched uranium, crashed in the area of the Great Slave Lake on 24 January 1978. The first stage of Morninglight was launched within hours-a massive air search for radiation hot-spots. Within four days, three radiation hot-spots were located, and several more within the next week.

A party of six meteorologists encamped in the Warden's Grove area, two of whom actually touched a fallen fragment, were evacuated to Edmonton for radiation tests; but they showed no signs of contamination. As for the local Chipewyan Indian population, apart from a missing pair of trappers who were feared to be camping near a hot-spot, the greatest danger seemed to be fear and bewilderment as to the nature of the search, plus the ominous appearance, in the settlement at Snowdrift, of a wolf which refused to be driven away and finally had to be shot.

The second stage of Morninglighta ground level survey-was scheduled for July, when the snows had melted. Shortly before it was to begin, uranium prospectors reported satellite debris in northern Saskatchewan, and the search was extended beyond the Great Slave Lake area. Morninglight finally covered some 90.000 square kilometres. from which over 3,000 pieces were recovered, mostly small particles, but with a few larger fragments, one of which was said to be-- "as big as a five gallon drum". One of the larger pieces was so radioactive that a special lead container had to be built by the University of Alberta. Another fragment. though. a $225 \mathrm{~cm} \times 50 \mathrm{~cm}$ stove-pipe shaped cylinder, was sufficiently "cool" to be loaned for temporary exhibition to the National Museum of Science and Technology in Ottawa.

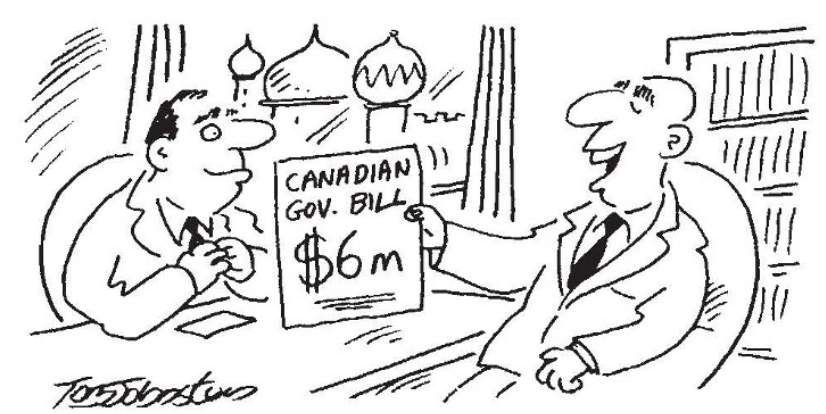
search. next time.

By the beginning of winter, when phase two of Morninglight ended, the Atomic Energy Board of Canada announced that the residual radiation risk in the impact area was minimal. Any remaining radioactive debris would soon decay to below natural background level, and the hazard to humans or wild life from accidentally ingested particles would be no greater than that from a medical x-ray examination. Nevertheless, as an additional precaution, the Federal Environment Department would monitor fish from the Great Slave Lake, while the Health Department would check the meat of migrating caribou herds.

Apart from these minor hazards, and the $\$ 13$ million bill, what are the lasting effects of the Kosmos-954 incident? First, the setting up, on Canada's initiative, of a UN working group to study the technical aspects and safeguards for nuclear power sources in space, the first meeting of which will take place later this year. Minor spinoffs include a considerable amount of practice in the aerial and ground location of radioactive debris, and the (at least temporary) appearance on the map of the name "Cosmos Lake" to denote the base camp of the aerial

Canada's claim against the Soviet Union will doubtless provide international lawyers with fascinating material on compensation norms and procedures. As far as the average Canadian is concerned, there remains a profound sense of thankfulness that the impact took place in a virtually uninhabited area-and considerable apprehension of what could happen

According to NASA officials, there is a $2 \%$ chance of debris from Skylab striking Canada. Moreover any such impact would occur south of latitude $50^{\circ} \mathrm{N}-\mathrm{a}$ band which includes all major Canadian cities except Edmonton and Calgary. Not surprisingly, Canadians are said to find the news of the forthcoming descent of Skylab to be, at the mildest. "somewhat disturbing".

Vera Rich 